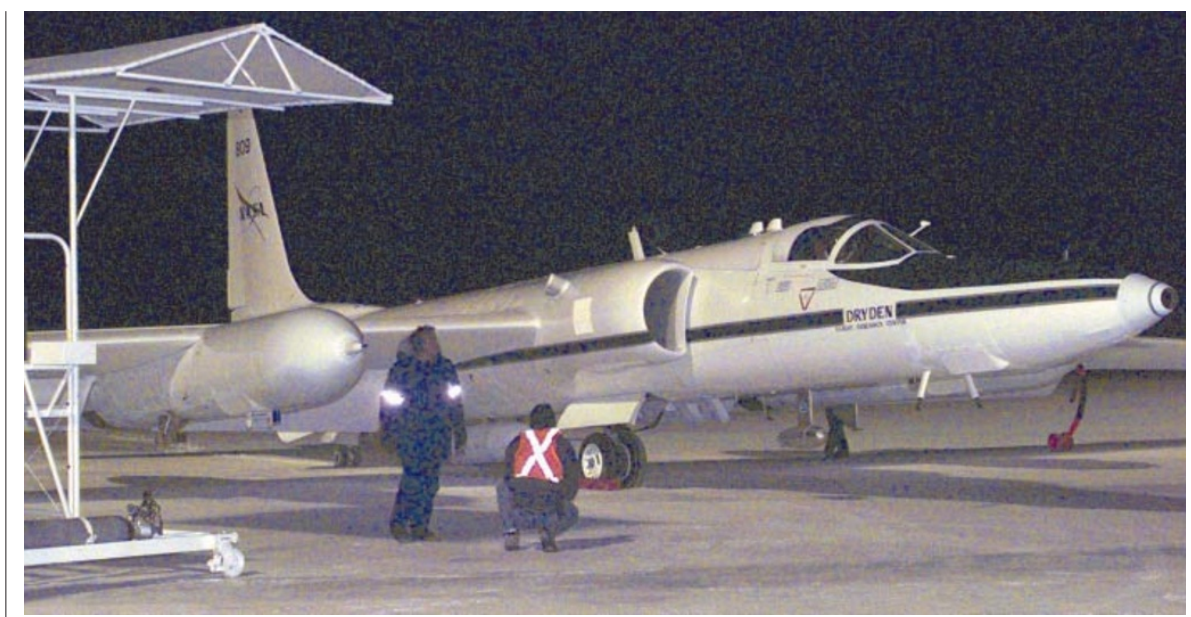

Into the vortex: NASA 'spy' planes have detected renewed ozone depletion in the Arctic stratosphere.

\title{
Global warming could be bad news for Arctic ozone layer
}

London

Environmental scientists have struggled for years to dispel a popular misconception that global warming and the thinning ozone layer are one and the same. But researchers who have just completed the largest ever survey of Arctic stratospheric ozone now warn that the two processes are, indeed, connected.

The bad news is that climate change could prolong ozone depletion in the Arctic by many years - despite the success of the Montreal Protocol of 1987 in reducing emissions of ozone-destroying chemicals.

Preliminary results, released this week, indicate that Arctic ozone loss is back at the alarming levels seen in the mid-1990s, when three successive winters, from 1994-95 to 1996-97, raised serious concerns. This year, at altitudes of around 18 kilometres, more than 60 per cent of the ozone was destroyed.

If the polar vortex - a stable mass of cold air that forms above the Arctic each wintergets cold enough, icy clouds form in the arid stratosphere. These polar stratospheric clouds harbour compounds containing chlorine and bromine, which destroy ozone.

For the past few months, that process has been under unprecedented scrutiny as more than 500 scientists have used a suite of research aircraft, balloons, satellites and ground-based instruments to monitor ozone depletion in the polar vortex.

The survey, which has just finished, was a collaboration between the European Commission, which funded the THESEO 2000 programme, and the United States, which called its project SOLVE. As Nature went to press, THESEO 2000 scientists were attempting a final balloon flight.

As part of the survey, an ER-2 aircraft - a civilian version of the U2 spy plane, from the US space agency NASA — flew from Kiruna in Sweden into the vortex, recording the concentration of ozone-destroying compounds and a wide spectrum of chemicals including nitrous oxide, carbon dioxide and methane.

Using these measurements, scientists were able to 'fingerprint' discrete parcels of stratospheric air, and then sample them repeatedly over a period of time with a range of instruments. These analyses revealed steady declines in ozone levels from January.

The extent of ozone destruction in a given year depends on how cold the vortex gets, and how long it lasts. In both 1997-98 and 1998-99, the vortex was a few degrees warmer than in the middle of the decade, and broke up before the spring, when increasing daylight hastens the chemical reactions that destroy ozone. As result, the Arctic retained most of its ozone.

The damage can also be limited by the presence in the stratosphere of nitric acid, which combines with chlorine and prevents it attacking ozone. But if ice particles in the polar stratospheric clouds sink down from the stratosphere, they take nitric acid with them. That happened this year. "There was extensive denitrification in the polar vortex," says Paul Newman of NASA's Goddard Space Flight Center in Greenbelt, Maryland.

The worry is that global warming will make this year's pattern more common. Most modellers believe that the Arctic stratosphere will cool as the lower atmosphere warms. Certainly, winters like this year's, in which the polar vortex has been cold and long-lasting, seem to be becoming more frequent. "One year does not prove a case," says Newman. "But we have seen quite a few years lately in which the stratosphere has been colder than normal." Peter Aldhous http://www.ozone-sec.ch.cam.ac.uk http://cloud1 .arc.nasa.gov/solve/
Japan squares up to conservationists over grey whale's status

Tokyo

The endangered Asian population of the grey whale could be threatened by Japanese proposals to downgrade the level of protection offered to the larger northeastern Pacific population, wildlife conservationists and researchers have warned.

Concern has been heightened by an analysis of whale products in Japanese shops, which showed that some of the meat on sale came from grey whales. The legal commercial hunting and trading of whales ended in 1986, although Japan is still allowed to hunt whales for research purposes.

Japan's Fisheries Agency wants to downlist three whale populations - the South Antarctic and northwestern Pacific Minke whale and northeastern Pacific grey whale. It plans to table the proposals at the eleventh meeting of the Convention for International Trade in Endangered Species of Wild Fauna and Flora, which starts next week in Nairobi, Kenya.

The agency says the proposals are based on research by the International Whaling Commission, which showed that the populations of these species are abundant. For example, the American grey whale population now totals more than 22,000. But, conservationists point out, the Asian population is estimated at no more than 100 individuals.

According to researchers from the University of Auckland, DNA analysis of the products on sale in Wakayama prefecture, on Japan's Pacific coast, showed that they came from a grey whale. But the researchers could not specify which population the DNA came from northeastern Pacific, American or Asian.

"The haplotype match could be explained by the low genetic diversity among grey whale populations," says Scott Baker, leader of the University of Auckland team. He explains that variation among Asian grey whales is low because of the small population size, whereas the 'bottleneck' - a period of reduced population size - caused by hunting of the American grey whale is thought to account for the lack of variation in the current population. "But the absence of a comparative genetic study between the two populations makes it difficult to draw any conclusion at this stage."

Past requests from researchers for tissue samples or genetic data from stranded whales killed by accident have been turned down repeatedly by Japanese 


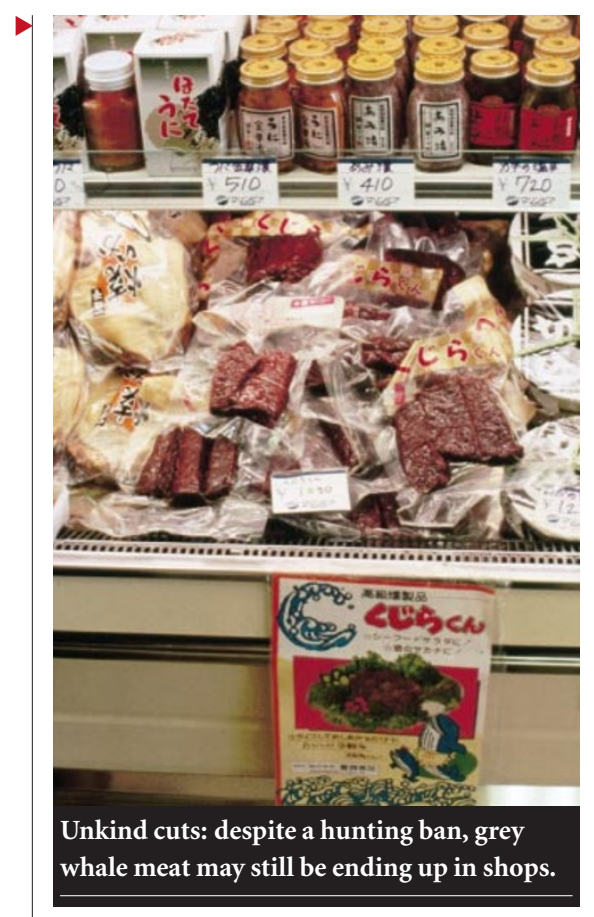

authorities. Some link this to Japanese regulations that allow the local use of meat from whales stranded or entangled in fishing gear regardless of their protective status.

The team believes it is possible that the products came from an Asian grey whale found floating in the Sea of Japan near the northern island of Hokkaido in 1996.

Although the whale was reported as being 'stranded', a later investigation revealed that it had been harpooned, with a 5-6 metre section of its tail expertly severed.

"It is possible that the products originate from long-term stockpiling of whales killed before 1986," says Baker. "But if they prove to be derived from the Hokkaido whale, the practice of stockpiling applies to illegal products, and the meat is being sent to places which could hardly be described as 'local'.

"Either way, undocumented and possibly illegal products from endangered species are turning up in the commercial market, and allowing trade in products from the American population should not be considered until this lack of transparency is solved."

The Fisheries Agency insists its proposed downlisting of the three whale species is not intended to lead to a resumption of trade in whale meat, but rather to pursue appropriate management of the species based on scientific findings.

But Naoko Nakamae, the Japanese representative of the International Fund for Animal Welfare, says such a move would put the Asian stock of grey whales at risk. "Unless the Japanese authority decides to make its data available to all, differentiating the two populations will remain impossible," she says. Asako Saegusa

\section{US court tests the breadth of patent protection on proteins}

Washington

Does a patent on a recombinantly produced protein give the owner rights to versions of that protein produced in other ways? This issue is being put to the test in a closely watched battle that opened in a Boston courtroom last week.

The biotechnology company Amgen, based in Thousand Oaks, California, is suing Transkaryotic Therapies (TKT), a small company in Cambridge, Massachusetts, alleging infringement of several patents on its blockbuster drug Epogen. Used to treat anaemia, Epogen is the trade name for erythropoietin (EPO), the hormone that stimulates the production of red blood cells.

Amgen developed the drug by cloning the human EPO gene and inserting it in Chinese hamster ovary cells, which then produce the hormone. US sales of Epogen for treating anaemia in kidney-dialysis patients totalled $\$ 1.8$ billion last year. Johnson \& Johnson, which sells Epogen for other uses under licence to Amgen, generated an additional \$2 billion in sales. Worldwide, the Epogen market is estimated to be worth $\$ 5$ billion a year.

Enter TKT. The company's researchers have developed an alternative way to produce EPO, taking advantage of the fact that all human cells carry the EPO gene, even though it is active only in kidney cells. In TKT's process, a promoter — or 'on-switch' — for the gene is inserted in human cells along with other regulatory and structural elements that guide the promoter to the EPO gene. The gene becomes activated and the cells begin producing the hormone.

TKT plans to market EPO produced in this way in collaboration with Aventis, the giant European drug-maker. It claims that its production process is distinct from Amgen's, so it is not infringing on the company's patents on the EPO gene and EPO production. Indeed, TKT's process does not require knowledge of the gene sequence.

More importantly, the Cambridge company disputes Amgen's patent rights to the EPO protein itself when made by mammalian cells in culture — rights that will be at the centre of the battle in US District Court. TKT and its advocates argue that Amgen is asserting far too broad a claim to a naturally occurring protein that was well characterized decades before Amgen cloned the gene and was granted its first patent in 1987. Indeed, Amgen scientists worked backwards from the protein's known amino-acid sequence to deduce the gene sequence.

If TKT prevails against Amgen, the implications would be considerable for Amgen's lucrative EPO market. They could also be felt by companies that have commercialized other therapeutic proteins such as interferon and Neupogen, another Amgen product.

TKT says that it has six additional proteins in its therapeutic pipeline, all made by the same promoter-insertion process. If it were to bring any of them to market - and presuming it prevailed in the inevitable court battles that would ensue - it could make considerable dents in what until now have been relatively exclusive and lucrative markets.

As a result, if TKT wins the lawsuit, "the industry may kind of go into shock", says Eric Schmidt, a biotechnology analyst at S. G. Cowen Securities in New York.

Amgen itself predicts dire consequences in such an event. "The real question is how strong is the US patent system," Gordon Binder, Amgen's chief executive, told The New York Times after the first day of preliminary court proceedings last week.

Some analysts back Amgen. "We believe that the Amgen patents do cover the TKT EPO product, if not the production process," says Dennis Harp of Deutsche Banc Alex. Brown, a global financial services company.

But others disagree. "If Amgen prevails, it suggests that US patents are so restrictive that it would actually discourage legitimate innovation," says Jonas Alsenas, an analyst at IND Bearings in New York. "If by solving half the problem you get rights to the full solution to the problem, that's not fair."

TKT declines to comment because the case is in litigation. Earlier this year, Richard Selden, its chief executive, told The New York Times: "We think that we're doing something fundamentally different" from Amgen.

David Kaye, an Amgen spokesman, says "We're confident in our patent position". The full trial of the case, which Amgen filed in 1997, is expected to begin in May. Whatever verdict is reached is almost certain to be appealed against.

Meredith Wadman

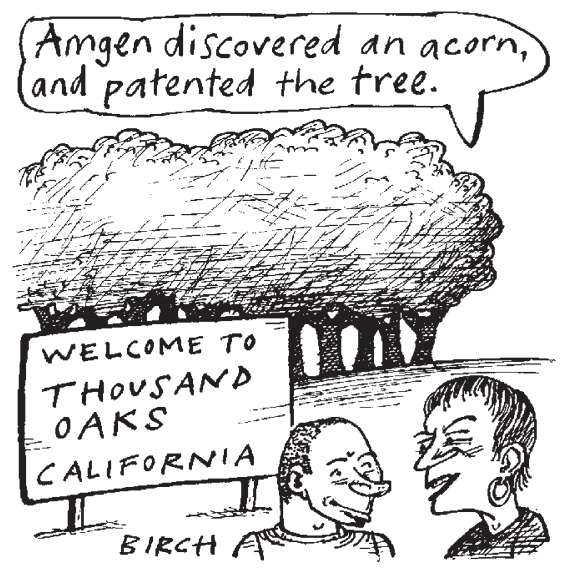

